\title{
Pengaruh Model Pembelajaran STAD berbasis Portofolio terhadap Kompetensi Pengetahuan Matematika
}

\author{
N.P.D Darmayanti1 ${ }^{*}$, I.W. Wiarta² ${ }^{2}$ G.N.S. Agustika ${ }^{3}$
}

1,2,3 Jurusan Pendidikan Guru Sekolah Dasar, Universitas Pendidikan Ganesha Singaraja, Indonesia

\author{
ARTICLEIN \\ $\mathrm{F} \mathrm{O}$ \\ Article history: \\ Received 12 May \\ 2018 \\ Received in revised \\ form \\ 18 June 2018 \\ Accepted 16 July \\ 2018 \\ Available online 28 \\ August 2018 \\ Kata Kunci: \\ STAD, portofolio, \\ kompetensi \\ pengetahuan \\ matematika. \\ Keywords : \\ STAD, portfolio, \\ competence of \\ mathematical \\ knowledge.
}

\begin{abstract}
A B S TR A K
Penelitian ini bertujuan untuk mengetahui pengaruh model pembelajaran STAD berbasis portofolio terhadap kompetensi pengetahuan matematika pada siswa kelas V SD Negeri 1 Ubud tahun pelajaran 2017/2018. Penelitian ini merupakan jenis penelitian eksperimen semu dengan rancangan nonequivalent control group design. Populasi penelitian ini adalah seluruh siswa kelas $V$ SD Negeri 1 Ubud tahun pelajaran 2017/2018 yang berjumlah116 orang siswa. Sampel ditentukan dengan menggunakan teknik random sampling. Sampel dalam penelitian ini adalah siswa kelas VB SD Negeri 1 Ubud dengan jumlah 40 siswa sebagai kelompok eksperimen dan siswa kelas VC SD Negeri 1 Ubud dengan jumlah 37 siswa sebagai kelompok kontrol. Pengumpulan data dilakukan dengan metode tes dengan bentuk tes objektif pilihan ganda biasa.Data yang diperoleh dianalisis menggunakan uji-t.Adapun nilai rata-rata kompetensi pengetahuan matematika siswa kelompok eksperimenyaitu81,25 sedangkan rata-rata siswa kelompok kontrol yaitu 74,62. Berdasarkan hasil penelitian tersebut dapat disimpulkan bahwa terdapat pengaruh model pembelajaran STADberbasis portofolio terhadap kompetensi pengetahuan matematika pada siswa kelas V SD Negeri 1 Ubud tahun pelajaran 2017/2018. Berdasarkan hasil penelitian disarankan bahwa hasil penelitian ini dapat dijadikan sebagai kajian yang relevan khususnya sebagai penunjang penelitian selanjutnya mengenai model pembelajaran STAD berbasis portofolio.
\end{abstract}

\section{A B S TR A C T}

This research aimed to knowthe effect of STAD learning model based on the portfolio of mathematic knowledge competence in fifth grade students of SD Negeri 1 Ubud in the academic year 2017/2018. This research is kind of quasi experiment research with nonequivalent control group design. The population of this study were all students of fifth grade of SD Negeri 1 Ubud in the academic year 2017/2018, amounting to 116 students. The sample was determined by using random sampling technique. The sample in this research is fifth grade B students of SD Negeri 1 Ubud with 40 students as experiment group and fifth grade C SD Negeri 1 Ubud students with 37 students as control group. The data collection is done by the test method with the usual double choice objective test form. The data obtained were analyzed using the t-test. The mean value of mathematics knowledge competence of the experimental group is 81.25 while the control group mean student is 74.62. Based on the results of this study can be concluded that there is the influence of STAD learning model based on the portfolio of knowledge competence of mathematics in fifth grade students of SD Negeri 1 Ubud in the academic year 2017/2018. Based on the results of research suggested that the results of this study can be used as a relevant study, especially as supporting the next research on STAD-based learning model portfolio.

\footnotetext{
* Corresponding author.

E-mail addresses: diahdarmayanti96@gmail.com (Diah Darmayanti)
} 


\section{Pendahuluan}

Pendidikan merupakan suatu proses mengubah tingkah laku anak didik agar menjadi manusia yang mampu mandiri dan sebagai anggota masyarakat dalam lingkungan alam sekitar dimana individu itu berada. Pendidikan tidak hanya mencakup pengembangan intelektualitas saja, akan tetapi lebih ditekankan pada proses pembinaan kepribadian anak didik. "Proses pendidikan adalah proses dalam rangka mempengaruhi peserta didik supaya mampu menyesuaikan diri sebaik mungkin dengan lingkungannya dan yang akan menimbulkan perubahan pada dirinya yang memungkinkan sehingga berfungsi sesuai kompetensinya dalam kehidupan masyarakat" (Sagala, 2012:4).

Dilihat dari definisi tersebut "pendidikan merupakan usaha sadar yang dilakukan oleh keluarga, masyarakat dan pemerintah melalui kegiatan bimbingan, pengajaran, atau latihan yang berlangsung di sekolah dan luar sekolah" (Sagala, 2012:4).Usaha sadar tersebut dilakukan dalam bentuk pembelajaran dimana ada pendidik yang melayani para siswanya melakukan kegiatan belajar, dan pendidik menilai atau mengukur tingkat keberhasilan belajar siswa tersebut dengan prosedur yang ditentukan.

Prosedur tersebut dilaksanakan sesuai dengan kurikulum yang berlaku."Kurikulum merupakan suatu rencana yang disusun untuk melancarkan proses belajar mengajar dibawah bimbingan dan tanggung jawab sekolah atau lembaga pendidikan beserta staf pengajarnya" (Nasution, 1999:5). Secara langsung maupun tidak langsung, penyampaian kurikulum dalam program pendidikan menuntut adanya tanggung jawab guru sebagai pelaksana proses belajar mengajar di sekolah. Peranan kurikulum sangatlah penting dalam pendidikan, maka dari itu berbagai upaya yang dilakukan pemerintah salah satunya dengan melakukan pengembangan kurikulum pendidikan di Indonesia.

Pengembangan kurikulum pendidikan di Indonesia telah mengalami penyempurnaan atau perbaikan terhadap kualitas pendidikan.Pada tahun 2013 Kementrian Pendidikan dan Kebudayaan telah mengembangkan kurikulum baru, sebagai penyempurnaan dan penguatan dari KTSP yang kemudian dikenal dengan kurikulum 2013."Kurikulum 2013 adalah dapat menghasilkan insan Indonesia yang produktif, kreatif, inovatif, dan afektif melalui penguatan sikap, keterampilan, dan pengetahuan yang terintegrasi" (al-Tabany, 2015:9). Pergantian kurikulum yang dilakukan tentu akan berpengaruh pada proses belajar mengajar. Dalam implementasi pembelajaran dengan kurikulum 2013, mata pelajaran menjadi tematik integratif yaitu mata pelajaran dengan menggunakan tema dalam berbagai mata pelajaran, diharapkan kompetensi pengetahuan matematika siswa menjadi lebih baik.

Matematika merupakan salah satu disiplin ilmu yang dapat meningkatkan kemampuan berpikir dan beragumentasi, memberikan kontribusi dalam penyelesaian masalah sehari-hari dan dalam dunia kerja, serta memberikan dukungan dalam pengembangan ilmu pengetahuan dan teknologi" (Susanto, 2015:185).Matematika dibelajarkan pada semua jenjang pendidikan, mulai dari tingkat sekolah dasar hingga perguruan tinggi.“Dibelajarkannya matematika kepada semua siswa mulai dari tingkat sekolah dasar (SD) adalah untuk membekali siswa berbagai kemampuan seperti kemampuan berpikir logis, analitis, kritis, dan kreatif, serta kemampuan bekerjasama" (Japa dan Suarjana, 2015:3).

Susanto (2015:195) menyatakan bidang studi matematika merupakan bidang studi yang berguna dan membantu dalam menyelesaikan berbagai masalah dalam kehidupan sehari-hari yang berhubungan dengan hitung menghitung atau yang berkaitan dengan urusan angka-angka berbagai macam masalah, yang memerlukan suatu keterampilan dan kemampuan untuk memecahkannya.

Berdasarkan observasi yang telah dilakukan di SD Negeri 1 Ubud, data hasil ulangan kompetensi pengetahuan matematika siswa kelas V masih ada yang dibawah Kriteria Ketuntasan Minimum (KKM). Terdapat kelas VA berjumlah 39 siswa, kelas VB berjumlah 40 siswa, dan kelas VC berjumlah 37 siswa. Jadi total keseluruhan siswa kelas V SD Negeri 1 Ubud adalah 116 orang siswa, 59 orang siswa sudah mencapai KKM dan 57 orang siswa yang belum mencapai KKM. Ini memperlihatkan bahwa 49\% siswa memiliki hasil belajar yang berada dibawah KKM. Rendahnya hasil kompetensi pengetahuan matematika siswa, disebabkan oleh beberapa faktor yaitu, penggunaan model pembelajaran inovatif dalam proses pembelajaran masih perlu divariasikan dan dioptimalkan karena hal tersebut dapat memudahkan guru dalam penyampaian informasi, menumbuhkan minat belajar siswa dan menciptakan suasana belajar yang menyenangkan. Selain itu, dalam proses pembelajaran matematika diketahui bahwa keantusiasan dan partisipasi aktif seluruh siswa dalam proses pembelajaran masih perlu dioptimalkan agar kompetensi pengetahuan matematika lebih baik lagi. Berdasarkan permasalahan tersebut, maka diperlukan adanya suatu inovasi pembelajaran yang dapat mengoptimalkan keantusiasan dan partisipasi aktif seluruh siswa sehingga kompetensi pengetahuan matematika siswa dapat optimal yaitu dengan menerapkan model pembelajaran Student Teams Achievement Division (STAD).

"Student Teams Achievement Division (STAD) merupakan salah satu model pembelajaran yang didalamnya terdapat beberapa kelompok kecil siswa dengan kemampuan akademik yang berbeda-beda saling bekerja sama untuk menyelesaikan tujuan pembelajaran" (Huda, 2013:201). Diawali dengan 
pengajaran, tes/kuis, pembagian kelompok, kegiatan belajar dalam tim, tes/kuis, kesimpulan pembelajaran, penghargaan prestasi tim. Model pembelajaran ini menekankan pada adanya aktivitas dan interaksi diantara siswa dalam menguasai materi pelajaran guna mencapai kompetensi pengetahuan yang maksimal.Model pembelajaran STAD dapat membuat siswa aktif membantu dan memotivasi semangat untuk berhasil bersama, interaksi antarsiswa seiring dengan peningkatan kemampuan mereka dalam berpendapat, meningkatkan kecakapan individu, dan meningkatkan kecakapan kelompok.

Guru selain dituntut dapat mengembangkan proses pembelajaran, faktor lainnya yang mempengaruhi keberhasilan pembelajaran adalah bagaimana guru dapat mengenali karakteristik peserta didik melalui penggunaan portofolio. Portofolio adalah semua benda yang berbentuk bukti fisik sebagai sesuatu yang menunjukkan hasil kinerja peserta didik. Portofolio dapat berbentuk kertas ulangan harian, kertas ulangan semesteran, buku pekerjaan rumah,sebagai bukti kinerja siswa.Pengajaran yang berfokus pada portofolio memberikan keuntungan.Salah satu keuntungan menggunakan portofolio dalam pembelajaran yaitu siswa dapat menggambarkan pembelajaran mereka sendiri dan cara-cara memperbaikinya. Selain itu portofolio juga memiliki beberapa kelebihan diantaranya guru dapat mengetahui perkembangan peserta didik secara individual dan peserta didik tidak perlu menunggu peserta didik lain untuk menyelesaikan kompetensi dasar yang sudah ditentukan.

Melalui penerapan model STAD berbasis portofolio, siswa dapat aktif membantu dan memotivasi semangat untuk berhasil bersama dan memperoleh kompetensi pengetahuan yang optimal. Jadi model pembelajaran ini mengacu pada belajar kelompok siswa dengan kemampuan akademik berbeda untuk menyelesaikan tujuan pembelajaran serta dapat membuat siswa aktif membantu dan memotivasi semangat untuk berhasil bersama untuk mencapai kompetensi pengetahuan yang maksimal, yang diintegrasikan dengan dokumen peserta didik yang menunjukkan hasil kinerjanya dalam rentangan waktu tertentu.

\section{Metode}

Penelitian ini dilaksanakan pada semester 2 tahun pelajaran 2017/2018 di kelas V SD Negeri 1 Ubud.Penelitian ini pada dasarnya bertujuan untuk mengetahui pengaruhmodel pembelajaran STAD berbasis portofolio terhadap kompetensi pengetahuan matematika siswa.Jenis penelitian ini adalah penelitian kuantitatif dengan desain eksperimen yaitu quasi experimental (eksperimen semu).Bentuk desain eksperimen yang digunakan adalah Nonequivalent control group design. Dalam desain ini terdapat dua kelompok, yaitu kelompok eksperimen dan kelompok kontrol.

Pretest diberikan kepada kelompok eksperimen dan kelompok kontrol. Pemberian pretest ini digunakan untuk mengetahui apakah sampel yang terpilih sudah setara atau tidak.Sejalan dengan hal tersebut, Dantes (2012:97) menyatakan "pemberian pretest biasanya digunakan untuk mengukur equivalensi atau penyetaraan kelompok". Setelah diberikan pretest dan dapat dinyatakan setara, kemudian diberikan perlakuan dalam pembelajaran, yaitu memberikan perlakuan dengan model pembelajaran STAD berbasis portofolio kepada kelompok eksperimen, sedangkan kelompok kontrol dibelajarkan pembelajaran konvensional.Kemudian setelah diberikan perlakuan, dilaksanakan posttest untuk mengetahui kompetensi pengetahuan matematika.Pelaksanaan penelitian ini terdiri dari tiga tahapan yaitu, tahap persiapan, pelaksanaan, dan akhir eksperimen.

Populasi merupakan kelompok yang digunakan sebagai subjek penelitian."Populasi adalah wilayah generalisasi yang terdiri atas objek/subjek yang mempunyai kualitas dan karakteristik tertentu yang ditetapkan oleh peneliti untuk dipelajari dan kemudian ditarik kesimpulannya" (Sugiyono, 2015:117).Sedangkan menurut (Agung, 2014:69) "Populasi adalah keseluruhan objek dalam suatu penelitian". Jadi dapat dirangkum populasi adalah kelompok atau keseluruhan kelompok atau objek yang mempunyai karakteristik dalam suatu penelitan..Populasi yang terlibat dalam penelitian ini adalah seluruh siswa kelas V SD Negeri 1 Ubud yang terdiri dari 3 kelas.Dengan demikian penelitian ini terdiri dari kelas VA, VB dan VC SD Negeri 1 Ubud yang berjumlah 116 orang siswa.

Data populasi secara rinci diuraikan dalam tabel berikut ini.

Tabel 01. Komposisi Populasi Siswa Kelas V SD Negeri 1 Ubud

\begin{tabular}{|c|c|c|c|}
\hline No. & Nama Sekolah & Kelas Populasi & Jumlah \\
\hline & & \multicolumn{2}{|c|}{ Siswa } \\
\hline 1. & SD Negeri 1 Ubud & VA & 39 \\
\hline 2. & SD Negeri 1 Ubud & VB & 40 \\
\hline 3. & SD Negeri 1 Ubud & VC & 37 \\
\hline
\end{tabular}




\begin{tabular}{|c|c|c|c|}
\hline & Nama Sekolah & Kelas Populasi & Jumlah \\
\hline Jumlah & & & 116 \\
\hline
\end{tabular}

Berdasarkan hasil wawancara yang diperoleh dari kepala sekolah serta guru kelas V di SD Negeri 1 Ubud yaitu bahwa kelas V dari tiga kelas yang ada di SD Negeri 1 Ubud setara secara akademik yang memiliki nilai rata-rata tidak jauh berbeda. Dikatakan setara, karena pengelompokkan siswa kedalam kelas-kelas disebar secara acak, saat pembentukan di kelas I, sehingga tidak terdapat kelas unggulan maupun non unggulan.

Dalam penelitian ini sampel yang dipilih adalah dua kelas, yaitu kelas eksperimen dan kelas kontrol. Penarikan sampel dilakukan dengan cara mengacak kelas, karena tidak diperkenankan merubah kelas yang telah terbentuk sebelumnya. Dengan kata lain pemilihan sampel dalam penelitian ini tidak dilakukan dengan pengacakan individu.

Kedua kelas yang terpilih sebagai sampel penelitian diberikan perlakuan yang berbeda, yaitu pembelajaran dengan menggunakan model pembelajaran STAD berbasis portofoliopada kelas eksperimen dan pembelajaran konvensional pada kelas kontrol.Teknik pengambilan sampel pada penelitian ini adalah random sampling. (Sugiyono, 2015:132) menyatakan "karena teknik pengambilan sampel adalah random, maka setiap anggota populasi mempunyai peluang yang sama untuk dipilih menjadi anggota sampel". Sejalan dengan pendapat tersebut Wirawan (2011) menyatakan sampel acak (random sample) adalah suatu sampel propabilitas dimana setiap anggota populasi mempunyai kesempatan yang sama untuk dipilih menjadi anggota sampel. Jadi, dapat dirangkum bahwa dalam penelitian ini tidak dilakukanpengacakan individu melainkan hanya pengacakan kelas, sehingga setiap kelas mendapatkan peluang yang sama untuk menjadi sampel penelitian.Hal ini dikarenakan jumlah populasi besar (banyak) sehingga kelas dipilih sebagaimana kelas yang telah terbentuk sebelumnya.

Pengambilan sampel dilakukan dengan cara menulis masing-masing nama kelas V di seluruh SD populasi pada kertas kemudian digulung. Gulungan tersebut dimasukkan ke dalam sebuah kotak kemudian dikocok. Setelah itu, peneliti mengambil satu gulungan kertas dan mengambil satu gulungan kertas lain tanpa memasukkan kembali gulungan kertas sebelumnya. Nama-nama kelas pada kedua gulungan kertas tersebut merupakan sampel penelitian.Berdasarkan hasil pengundian maka diperoleh 2 kelas sebagai sampel yaitu kelas VB SD Negeri 1 Ubud yang berjumlah 40 orang siswa dan kelas VC SD Negeri 1 Ubud yang berjumlah 37 orang siswa.

Metode pengumpulan data adalah cara yang dilakukan peneliti untuk mengumpulkan data. Salah satu metode yang dapat digunakan untuk mengumpulkan data adalah metode tes.Metode pengumpulan data pada penelitian ini menggunakan metode tes dan instumen yang digunakan untuk mengumpulkan data kompetensi pengetahuan matematika adalah tes objektif dalam bentuk pilihan ganda biasa. Untuk penskoran yaitu skor 0 untuk siswa yang menjawab salah dan skor 1 untuk siswa yang menjawab benar pada setiap item butir soal. Jadi skor setiap jawaban dijumlahkan dibagi dengan skor maksimal dikali 100 sehingga didapat nilai kompetensi pengetahuan matematika yang bergerak dari kisaran 0-100.

Data yang diperoleh pada penelitian ini dianalisis menggunakan analisis statistik deskriptif dan analisis statistik inferential.Metode analisis data deskriptif dalam penelitian ini digunakan untuk mendeskripsikan datakompetensi pengetahuan matematika siswa yang dibelajarkan dengan model pembelajaran STAD berbasis portofolio dan kompetensi pengetahuan matematika siswa yang dibelajarkan dengan pembelajaran konvensional yang menggunakan pendekatan saintifik. Analisis statistik yang digunakan dalam penelitian ini, yatu mean, median, modus, variansi, dan standar deviasi.

Statistik inferensial merupakan teknik analisis data yang digunakan untuk menentukan sejauh mana kesamaan antara hasil yang diperoleh dari suatu sampel dengan hasil yang akan didapatkan pada keseluruhan populasi. Analisis statistik inferensial yang digunakan dalam penelitian ini adalah uji-t $(t-$ test).Untuk dapat menggunakan teknik analisis tersebut dibutuhkan data yang berdistribusi normal dan homogen.Maka dari itu, perlu dilakukan uji normalitas sebaran data dan uji homogenitas varians untuk memenuhi prasyarat yang dibutuhkan untuk menggunakan teknik analisis uji-t $(t$-test $)$.

\section{Hasil dan Pembahasan}

Data yang dianalisis pada penelitian ini adalah data hasil kompetensi pengetahuan matematika siswa kelas V Bab Data pada kelompok eksperimen dan kelompok kontrol SD Negeri 1 Ubud yang mengikuti pembelajaran dengan pembelajaran konvensional.Datakompetensi pengetahuan matematikasiswa diperoleh dari hasil posttest yang diberikan pada akhir penelitian.Kelas VB SD Negeri 1 Ubud terpilih sebagai kelompok eksperimen dengan jumlah siswa 40 orang dan Kelas VC SD Negeri 1 Ubud terpilih sebagai kelompok kontrol dengan jumlah siswa 37 orang. 
Data yang dianalisis dalam penelitian ini adalah data kompetensi pengetahuan matematika.Data pretest digunakan untuk penyetaraan kedua kelompok sebelum diberikan perlakuan. Hasil pretest kedua kelompok sampel dapat dilihat pada grafik steam and leaf berikut ini.

\begin{tabular}{lll}
\hline Kelas VB Leaves & Pretest Steam & Kelas VC Leaves \\
\hline 77733 & 5 & 000033377 \\
3300000 & 6 & 000000337 \\
77733000000000 & 7 & 00033333777 \\
7730000000 & 8 & 00077 \\
0000 & 9 & 000 \\
\hline
\end{tabular}

Gambar 01. Grafik Steam and Leaf Data Pretest Kompetensi Pengetahuan Matematika (Sumber: Darsyah, 2014)

Berdasarkan grafik pada gambar 01, hasil pretest terendah pada siswa kelas VB adalah 53 dengan frekuensi sebanyak 2, dan kelas VC adalah 50 dengan frekuensi sebanyak 4. Sedangkan nilai pretest tertinggi pada siswa kelas VB adalah 90 dengan frekuensi sebanyak 4, dan kelas VC adalah 90 dengan frekuensi sebanyak 3.

Berikut ini adalah ringkasan data hasil pretest berupa rata-rata (mean), median, modus, variansi, standar deviasi, nilai maksimum dan nilai minimum. Pretest kompetensi pengetahuan matematika yang digunakan sebagai instrumen penelitian berjumlah 30 butir soal pilihan ganda biasa. Berikut adalah ringkasan data pretest kompetensi pengetahuan matematika sampel penelitian.

Tabel 02. Ringkasan Data Pretest Kompetensi Pengetahuan Matematika Sampel Penelitian

\begin{tabular}{lll}
\hline Hasil Analisis & Kelas VB & Kelas VC \\
\hline Rata-rata & 72,18 & 68,00 \\
\hline Median & 70 & 70 \\
\hline Modus & 70 & 60 \\
\hline Variansi & 120,66 & 156,50 \\
\hline Standar Deviasi & 10,98 & 12,51 \\
\hline Nilai Maksimum & 90 & 90 \\
\hline Nilai Minimum & 53 & 50 \\
\hline
\end{tabular}

Berdasarkan tabel 02, diketahui rata-rata (mean) siswa kelas VB data berpusat di sekitaran nilai 72,18. Selanjutnya rata-rata (mean) tersebut dikonversikan ke dalam kategori Penilaian Acuan Patokan (PAP) dengan skala 5. Nilai rata-rata kompetensi pengetahuan matematika kelas VB adalah 72,18. Berdasarkan PAP skala 5 siswa kelas VB berada pada kriteria cukup. Selanjutnya median pada data pretest kelas VB adalah 70 dan nilai yang sering muncul yaitu 70. Penyebaran data terhadap rata-rata sebesar 120,66 dengan penyimpangan skor terhadap rata-rata sebesar 10,98. Pada siswa kelas VC diketahui data berpusat di sekitaran nilai 68,00. Selanjutnya rata-rata (mean) tersebut dikonversikan ke dalam kategori Penilaian Acuan Patokan (PAP) dengan skala 5. Nilai rata-rata kompetensi pengetahuan matematika kelas VC adalah 68,00. Berdasarkan PAP skala 5 siswa kelas VC berada pada kriteria cukup. Selanjutnya median pada data pretest kelas VC adalah 70 dan nilai yang sering muncul yaitu 60 . Penyebaran data terhadap rata-rata sebesar 156,50 dengan penyimpangan skor terhadap rata-rata sebesar 12,51.

Setelah kedua kelompok sampel dinyatakan setara, maka pemberian perlakuan pada kelompok eksperimen dapat dilakukan.Kemudian pada akhir pertemuan, siswa diberikan posttest yang dianalisis 
untuk memperoleh hasil kompetensi pengetahuan matematika siswa. Hasil posttest kelompok eksperimen dan kelompok kontrol dapat dilihat pada grafik steam and leaf berikut ini.

\begin{tabular}{lll}
\hline Kelompok Eksperimen Leaves & $\begin{array}{l}\text { Posttest } \\
\text { Steam }\end{array}$ & Kelompok Kontrol Leaves \\
\hline 99 & 5 & 6699 \\
96 & 6 & 2999 \\
8888888555 & 7 & 22222222222255588 \\
77774444444111111111 & 8 & 111111177 \\
774111 & 9 & 114
\end{tabular}

Gambar 02. Grafik Steam and Leaf Data Posttest Kompetensi Pengetahuan Matematika

(Sumber: Darsyah, 2014)

Berdasarkan grafik pada gambar 4.2, hasil posttest terendah pada siswa kelompok eksperimen adalah 59 dengan frekuensi sebanyak 2, dan kelompok kontrol adalah 56 dengan frekuensi sebanyak 2. Sedangkan nilai posttest tertinggi pada siswa kelompok eksperimen adalah 97 dengan frekuensi sebanyak 2, dan kelompok kontrol adalah 94 dengan frekuensi sebanyak 1.

Tes kompetensi pengetahuan matematika yang digunakan sebagai instrumen penelitian berjumlah 32 butir soal pilihan ganda biasa yang telah diuji validitas, reliabilitas, daya beda, dan tingkat kesukaran. Berikut adalah ringkasan data posttest kompetensi pengetahuan matematika kelompok eksperimen dan kelompok kontrol.

Tabel 03. Ringkasan Data Posttest Kompetensi Pengetahuan Matematika Kelompok Eksperimen dan Kelompok Kontrol

\begin{tabular}{lll}
\hline Hasil Analisis & Kelompok Eksperimen & Kelompok Kontrol \\
\hline Rata-rata & 81,25 & 74,62 \\
\hline Median & 81 & 72 \\
\hline Modus & 81 & 72 \\
\hline Variansi & 69,06 & 84,58 \\
\hline Standar Deviasi & 8,31 & 9,20 \\
\hline Nilai Maksimum & 97 & 94 \\
\hline Nilai Minimum & 59 & 56 \\
\hline
\end{tabular}

Berdasarkan ringkasan data posttest kompetensi pengetahuan matematika pada kelompok eksperimen data berpusat di sekitaran nilai 81,25. Selanjutnya rata-rata (mean) tersebut dikonversikan ke dalam kategori Penilaian Acuan Patokan (PAP) dengan skala 5. Nilai rata-rata kompetensi pengetahuan matematika kelompok eksperimen adalah 81,25. Berdasarkan PAP skala 5 siswa kelompok eksperimen berada pada kriteria baik.Selanjutnya median pada data posttest kelompok eksperimen adalah 81 dan nilai yang sering muncul yaitu 81. Penyebaran data terhadap rata-rata sebesar 69,06 dengan penyimpangan skor terhadap rata-rata sebesar 8,31. Pada kelompok kontrol diketahui data berpusat di sekitaran nilai 74,62. Selanjutnya rata-rata (mean) tersebut dikonversikan ke dalam kategori Penilaian Acuan Patokan (PAP) dengan skala 5. Nilai rata-rata kompetensi pengetahuan matematika kelompok kontrol adalah 74,62. Berdasarkan PAP skala 5 siswa kelompok kontrol berada pada kriteria cukup.Selanjutnya median pada data posttest kelompok kontrol adalah 72 dan nilai yang sering muncul 
yaitu 72. Penyebaran data terhadap rata-rata sebesar 84,58 dengan penyimpangan skor terhadap ratarata sebesar 9,20.

Sebelum dilakukan uji hipotesis dengan uji-t, terlebih dahulu dilakukan uji asumsi analisis data yang meliputi, uji normalitas sebaran data dan uji homogenitas variansi.

Berdasarkan hasil uji normalitas kelompok eksperimen, diperoleh maksimum $\left|\mathrm{F}_{\mathrm{T}}-\mathrm{Fs}_{\mathrm{s}}\right|=0,148$, kemudian nilai tersebut dibandingkan dengan nilai tabel kolmogorov-smirnov dengan taraf signifikan 5\% $(\mathrm{N}=40)=0,210$. Hal ini menunjukkan bahwa nilai maksimum $\left|\mathrm{F}_{\mathrm{T}}-\mathrm{Fs}\right|<$ nilai tabel kolmogorov-smirnov berarti data kompetensi pengetahuan matematika kelompok eksperimen berdistribusi normal.

Berdasarkan hasil uji normalitas kelompok kontrol, nilai maksimum $\quad|| F_{T}-F_{S} \mid=0,153$, kemudian nilai tersebut dibandingkan dengan nilai tabel kolmogorov-smirnov dengan taraf siginifikan $5 \%(\mathrm{~N}=37)=0,218$. Hal ini menunjukkan bahwa nilai maksimum $\left|\mathrm{F}_{\mathrm{T}}-\mathrm{Fs}\right|<$ nilai tabel kolmogorovsmirnov berarti data kompetensi pengetahuan matematika kelompok kontrol berdistribusi normal.

Uji homogenitas data kompetensi pengetahuan matematika kelompok eksperimen dan kelompok kontrol diperoleh $\mathrm{F}_{\text {hitung }}=1,22$ dan $\mathrm{F}_{\text {tabel }}=1,69$. Hal ini berarti $\mathrm{F}_{\text {hitung }}<\mathrm{F}_{\text {tabel }}$, sehingga data kedua kelompok memiliki variansi yang homogen.

Berdasarkan hasil uji normalitas sebaran data dan uji homogenitas varians diketahui bahwa data yang diperoleh dari kelompok eksperimen dan kelompok kontrol berdistribusi normal dan memiliki variansi yang homogen. Karena data yang diperoleh telah memenuhi uji prasyarat, kemudian dilanjutkan dengan uji hipotesis menggunakan analisis uji-t dengan rumus polled varians.

Dari hasil analisis diperoleh $t_{\text {hitung }}=3,323$ dan $t_{\text {tabel }}=2,000$ pada taraf siginifikansi $5 \%$ dengan $\mathrm{dk}=$ 75. Oleh karena $t_{\text {hitung }}>t_{\text {tabel }}(3,323>2,000)$ maka $H_{0}$ yang menyatakan bahwa tidak terdapat perbedaankompetensi pengetahuan matematika antara kelompok siswa yang dibelajarkan melalui model pembelajarn STAD berbasis portofolio dan kelompok siswa yang dibelajarkan melalui pembelajaran konvensional pada siswa kelas V SD Negeri 1 Ubud tahun pelajaran 2017/2018 ditolak, dan $\mathrm{H}_{\mathrm{a}}$ yang menyatakan terdapat perbedaankompetensi pengetahuan matematika antara kelompok siswa yang dibelajarkan melalui model pembelajaran STAD berbasis portofolio dan kelompok siswa yang dibelajarkan melalui pembelajaran konvensional pada siswa kelas V SD Negeri 1 Ubud tahun pelajaran 2017/2018diterima. Sehingga dapat dikatakan bahwa model pembelajaran STAD berbasis portofolio berpengaruh terhadap kompetensi pengetahuan matematika siswa kelas V SD Negeri 1 Ubud tahun pelajaran 2017/2018.

Tabel 04. Rekapitulasi Hasil Analisis Data Kompetensi Pengetahuan Matematika Menggunakan Uji-t

\begin{tabular}{|c|c|c|c|c|c|c|c|c|}
\hline No & Sampel & $\mathrm{N}$ & $\mathrm{dk}$ & $\mathrm{X}$ & $\mathrm{S}^{2}$ & $\mathrm{~T}_{\text {hit }}$ & $\mathrm{T}_{\mathrm{tab}}$ & Kriteria \\
\hline 1 & Eksperimen & 40 & \multirow[t]{2}{*}{75} & 81,25 & 69,06 & \multirow[t]{2}{*}{3,32} & 2,00 & \multirow{2}{*}{$\begin{array}{l}\mathrm{H}_{0} \\
\text { ditolak }\end{array}$} \\
\hline 2 & Kontrol & 37 & & 74,62 & 84,58 & & & \\
\hline
\end{tabular}

Pengaruh model pembelajaran STADterhadap kompetensi pengetahuan matematika siswa dilihat dari perolehan hasil analisis deskriptif antara kedua kelompok sampel.Secara deskriptif rata-rata kompetensi pengetahuan matematika siswa kelompok eksperimen $\bar{X}=81,25$ dan rata-ratakompetensi pengetahuan matematika siswa kelompok kontrol $\bar{X}=74,62$. Berdasarkan hal tersebut, dapat dinyatakan kedua kelompok sampel yang memiliki kemampuan yang setara setelah diberikan perlakuan berupa model pembelajaran STAD berbasis portofoliopada kelompok eksperimen dan pembelajaran konvensional pada kelompok kontrol diperoleh hasil kompetensi pengetahuan matematika yang berbeda. Pengaruh model pembelajaran STAD berbasis portofolio terhadap kompetensi pengetahuan matematika siswa disebabkan karena adanya perbedaan langkah-langkah pembelajaran.

Pada kelompok eksperimen, siswa dibelajarkan menggunakan model pembelajaranSTAD terdapat beberapa kelompok kecil siswa dengan kemampuan akademik yang berbeda-beda saling bekerja sama untuk menyelesaikan tujuan pembelajaran. Diawali dengan pengajaran, tes/kuis, pembagian kelompok, kegiatan belajar dalam tim, tes/kuis, kesimpulan pembelajaran, penghargaan prestasi tim. Model pembelajaran ini menekankan pada adanya aktivitas dan interaksi diantara siswa dalam menguasai materi pelajaran guna mencapai kompetensi pengetahuan yang maksimal.Model pembelajaran STAD dapat membuat siswa aktif membantu dan memotivasi semangat untuk berhasil bersama, interaksi antarsiswa seiring dengan peningkatan kemampuan mereka dalam berpendapat, meningkatkan kecakapan individu, dan meningkatkan kecakapan kelompok.yang diintegrasikan dengan dokumen peserta didik yang menunjukkan hasil kinerjanya dalam rentangan waktu tertentu.

Berbeda dengan kelompok kontrol yang hanya menerapkan pendekatan saintifik. Proses pembelajaran yang berlangsung perludioptimalkan karena keantusiasan dan partisipasi aktif siwa perlu dioptimalkan dalam muatan materi matematika. Hal ini menyebabkan siswa kurang semangat dalam 
mengikuti pelajaran dan terkesan jenuh dengan kegiatan pembelajaran yang monoton. Dengan demikian, perbedaan hasil kompetensi pengetahuan matematika siswa dapat dilihat dari kegiatan pembelajaran yang dilakukan pada kelompok eksperimen dan kelompok kontrol, hasil analisis uji hipotesis, dan nilai rata-rata kelompok siswa yang dibelajarkan menggunakan model pembelajaran STAD berbasis portofolio dengan kelompok siswa yang dibelajarkan menggunakan pembelajaran konvensional.

Hasil penelitian ini memperkuat hasil penelitian yang relevan yang dilaksanakan olehPutra (2013) yang menyatakan bahwa model pembelajaran kooperatif tipe STAD berpengaruh terhadap hasil belajar matematika siswa kelas V SD Gugus Ubud Tahun Ajaran 2012/2013. Hal tersebut terjadi karena model STAD dapatmembantu dan memotivasi semangat untuk berhasil bersama.

Berdasarkan paparan tersebut, dapat dikatakan bahwa model pembelajaran STAD berbasis portofolioberpengaruh terhadap kompetensi pengetahuan matematika siswa kelas V SD Negeri 1 Ubud tahun pelajaran 2017/2018.

\section{Simpulan dan Saran}

Berdasarkan hasil analisis statistik deskriptif kompetensi pengetahuan matematika kelompok eksperimen terdapat 40 orang siswa dengan nilai tertinggi 97 dan nilai terendah 59, serta diperoleh nilai rata-rata (mean) 81,25 termasuk kriteria baik sesuai dengan kriteria PAP skala lima. Selanjutnya dapat pula di deskripsikan bahwa median dan modus yaitu 81, variansi data kompetensi pengetahuan matematika adalah 69,06 dengan standar deviasi 8,31.

Berdasarkan hasil analisis statistik deskriptif kompetensi pengetahuan matematika kelompok kontrol terdapat 37 orang siswa dengan nilai tertinggi 94 dan nilai terendah 56, serta diperoleh nilai diperoleh rata-rata (mean) 74,62 termasuk kriteria cukup sesuai dengan kriteria PAP skala lima. Selanjutnya dapat pula di deskripsikan bahwa median dan modus yaitu 72 , variansi data kompetensi pengetahuan matematika adalah 84,58 dengan standar deviasi 9,20.

Berdasarkan hasil analisis hipotesis dengan menggunakan uji-t diperoleh $t_{h i t u n g}=3,323$ dan dengan taraf signifikan $5 \% \mathrm{dk}=75$ diperoleh $\mathrm{t}_{\text {tabel }}=2,000$ maka 3,323 > 2,000, ini berarti bahwa terdapat perbedaan yang signifikan kompetensi pengetahuan matematika antara kelompok siswa yang dibelajarkan melalui model pembelajaran STAD berbasis portofolio dan kelompok siswa yang dibelajarkan melalui pembelajaran konvensional pada siswa kelas V SD Negeri 1 Ubud tahun pelajaran 2017/2018. Rata-rata kompetensi pengetahuan matematika siswa kelompok eksperimen lebih besar dari rata-rata kompetensi pengetahuan matematika siswa kelompok kontrol ( $\bar{X}=81,25>\bar{X}=74,62$ ). Jadi dapat disimpulkan bahwa model pembelajaran STAD berbasis portofolio berpengaruh terhadap kompetensi pengetahuan matematika pada siswa kelas V SD Negeri 1 Ubud tahun pelajaran 2017/2018.

Adapun saran yang dapat disampaikan melalui penelitian ini, yaitu saran kepada guru, sekolah, dan peneliti lain. Berdasarkan temuan penelitian, disarankan guru dapat menerapkan inovasi-inovasi baru dalam merancang suatu pembelajaran untuk dapat memotivasi dan memfasilitasi potensi yang dimiliki oleh siswa dengan menggunakan model pembelajaran STADberbasis portofolio sehingga dapat mencapai kompetensi pengetahuan matematika yang optimal.

Sekolah dapat melaksanakan sosialisasi secara berkelanjutan mengenai inovasi-inovasi pembelajaran kepada guru-guru dalam membelajarkan siswa dengan tujuan perubahan paradigma proses pembelajaran di sekolah yang menunjang kredibelitas menjadi sekolah yang unggul dan inovatif.

Sebagai peneliti bidang sejenis agar dapat memanfaatkan hasil penelitian ini sebagai referensi untuk melaksanakan penelitian selanjutnya atau menemukan inovasi kegiatan pembelajaran lainnya yang bermakna bagi siswa.

\section{Daftar Rujukan}

Adi, I N. S. M. \& N. N. Padmadewi, N. M. Ratminingsih.2017." The Effect Of Stad Upon Students With Different Level Of Self Esteem Toward Reading Comprehension Of Eleventh Grade Students Of Sman 1 Kediri Tabanan In The Academic Year 2013/2014". International Journal of Language and Literature Vol 1, No 3 (2017).

Agung, A.A. Gede. 2014. Metodelogi Penelitian Pendidikan. Singaraja:Universitas Pendidikan Ganesha.

Al-Tabany, Trianto Ibnu Badar.2015. Mendesain Model Pembelajaran Inovatif, Progresif, Dan Kontekstual.Jakarta: Prenadamedia Group.

Dantes, Nyoman. 2012. Metode Penelitian. Yogyakarta: Andi. 
Huda, Miftahul. 2013. Model-Model Pengajaran Dan Pembelajaran. Yogyakarta: Pustaka Pelajar.

Indrawati, Ni Luh Gede Eka. 2017. "Penerapan Model Pembelajaran Kooperatif Tipe Student Team Achievement Divisions (Stad) Untuk Meningkatkan Hasil Belajar Matematika Siswa Kelas VI SD No. 1 Sading Kecamatan Mengwi Kabupaten Badung Semester I Tahun Pelajaran 2016/2017". Journal of Education Action Research Vol 1, No 2 (2017): August 2017.

Japa dan Suarjana. 2015. Buku Ajar Matematika. Singaraja: Universitas Pendidikan Ganesha.

Jayano,Dw. Md. R. Dwi \& I Gst. Ngr. Japa I Md. Tegeh.2013." Pengaruh Model Pembelajaran Kooperatif Tipe Stad Bermuatan Catur Pramana Terhadap Hasil Belajar Matematika Kelas V Sdn 1 Sangsit". MIMBAR PGSD Undiksha Vol 1, No 1 (2013).

Nasution. 1999. Kurikulum Dan Pengajaran. Jakartta: PT Bumi Aksara.

Peraturan Menteri Pendidikan dan Kebudayaan Republik Indonesia Nomor 104 Tahun 2014 Tentang Penilaian Hasil Belajar Oleh Pendidik pada Pendidikan Dasar dan Pendidikan Menengah, 2014. Jakarta: Kemendikbud.

Peraturan Menteri Pendidikan dan Kebudayaan Republik Indonesia Nomor 20 Tahun 2016 Tentang Standar Kompetensi Lulusan Pendidikan Dasar Dan Menengah, 2016. Jakarta: Kemendikbud.

Pujiono, Rudi.2017. "Penerapan Model Pembelajaran Kooperatif Tipe Student Team Achievement Divisions (Stad) Untuk Meningkatkan Motivasi Dan Hasil Belajar Ipa Siswa Kelas V B Sdn 047 Tarakan". Journal of Education Research and Evaluation Vol 1, No 4 (2017).

Putra. 2013. "Pengaruh Penerapan Model Pembelajaran Kooperatif Tipe STAD Terhadap Hasil Belajar Matematika Siswa Kelas V SD Gugus Ubud". Univesitas Pendidikan Ganesha, Volume 1.

Sagala, Syaiful. 2012. Konsep Dan Makna Pembelajaran. Bandung: Alfabeta.

Setyosari, H. Punaji. 2015. Metode Penelitian Pendidikan \& Pengembangan.Jakarta: Prenadamedia Group.

Sudana, I Putu Ari \& I Gede Astra Wesnawa.2017.” Penerapan Model Pembelajaran Kooperatif Tipe STAD Untuk Meningkatkan Hasil Belajar IPA". Jurnal Ilmiah Sekolah Dasar Vol 1, No 1 (2017): Februari 2017.

Sugiyono. 2015. Metode Penelitian Pendidikan. Bandung: Alfabeta.

Susanto, Ahmad. 2015. Teori Belajar \& Pembelajaraan Di Sekolah Dasar.Jakarta: Prenadamedia Group.

Wahyuni. 2014. "Pengaruh Penerapan Model Pembelajaran Kooperatif Tipe STAD Berbasis Interaksi Sosial Terhadap Hasil Belajar IPS Siswa Kelas V SD”. Univesitas Pendidikan Ganesha, Volume 2.

Wirawan. 2011. Evaluasi Teori, Model, Standar, Aplikasi, dan Profesi. Jakarta: Rajawali Pers 